\title{
Disrupting Higher Education: Assessing the Impact of COVID-19 on Higher Education Institutions in Indonesia and the United States
}

\author{
Tristan Prodjomaroeto, Ali Muhyidin \\ Universitas Indonesia \\ Email address: tristan.prodjomaroeto@ui.ac.id
}

\begin{abstract}
This paper examines the impact of COVID-19 on higher education institutions in Indonesia and the United States using qualitative document analysis dedicated to higher education institutions. The findings suggest that the perplexing problems found in higher education institutions have downcutting the ability to achieve equal distribution of quality education, and the crisis caused by COVID-19 has made higher education less accessible specifically towards under-privilege students. Hence, the utilization of EdTech is pivotal in creating equal access and distribution in higher education. It is expected that the prevalent use of such technology is expected to stick in the long run.
\end{abstract}

Keywords: Higher education institution, COVID-19, Impact, Disruption, EdTech

\section{INTRODUCTION}

The outbreak of COVID-19 has massively struck higher education institutions both in Indonesia and the United States. Most universities are imposing online distance learning for their students to curb the spread of the virus. The existing problems perplexing higher education institutions, added with the crisis of COVID-19 has made higher education less accessible specifically for underprivilege society. Higher education institutions has been without its predicament. In Indonesia, higher education has been massively privatized, seen from the number of private higher education institutions that massively outweigh the number of public institutions. Despite the massive expansion of Indonesia's primary education, higher education institutions in Indonesia still struggles to increase its participation, accessibility, and ensuring equal dissemination of education. Such similarities are also evident in the United States. Higher education institutions in the United States have transformed into a costly commodity with their tuition kept on increasing over the past decades, making the cost of higher education substantially higher. Students are paying more money through increased tuition fees, and many more are taking debt to finance their education. This is concerning for students coming from a disadvantaged background since it hampers their financial capability in the long run by paying up education debts, exacerbating economic inequalities even further.
The issues surrounding disruptive innovation in higher education are evident by the work of (Christensen \& Eyring, 2011), who uses disruptive innovation theory in explaining how universities adapt to the evolving technological innovation in the modern century. This theory explains two types of innovation which are: sustaining innovation and disruptive innovation. Sustaining innovation focusses on harnessing technology to make something "bigger or better." By contrast, disruptive innovation disrupts the "bigger and better cycle" by creating new product or service to the market that might be not as good as the traditional offering with a more affordable and easy-to-use product or service (p. xxiv). Disruptive innovation disrupts the existing market by introducing new solutions that cater to underserved consumers. Christensen and Eyring (2011) stated that higher education institutions experienced an absence in utilizing disruptive technology. Teaching, learning, examination method remained largely the same throughout the century. The emergence of computers and the internet was often used to enhance teaching and learning methods rather than supplant them. This paper will focus its discussion on the impacts of COVID-19 towards higher education institutions in Indonesia and the United States. A comparative analysis will be employed by looking at their respective growth, student enrollment, tuition fees, consumer index during COVID-19. 


\section{METHOD}

The discussion of disruptive innovation in universities are blaring across scholars in contemporary society, as evidenced by the work of (Christensen \& Eyring, 2011), discussing disruptive innovation towards higher education institutions. The theory is used as a conceptual framework for examining how the pandemic will hugely shift higher education institutions. The trajectory of disruption is expected to differ between Indonesia and the United States, seeing the different landscapes surrounding their higher education institutions. This paper employed qualitative document analysis as a research method to explore higher education institutions in Indonesia and the United States. The author gathers previous studies, research, reports, statistical data dedicated to higher education institutions. The impact of COVID-19 towards higher education institutions were also examined further in the discussion to provide explanation and analysis on how the pandemic provides further challenges and disruption towards higher education institutions. The author applies comparative analysis to provide an overview of higher education institutions in Indonesia and the United States.

\section{RESULTS AND DISCUSSION}

\section{Higher Education Overview in Indonesia}

Higher education in Indonesia is offered through various degrees such as Diploma (D1, D2, D3, and D4), bachelor's degree (S1), a postgraduate degree (S2), doctoral programs (S3). Since the implementation of the Education Act in 1961, higher education in Indonesia has experienced steady growth, followed by the exponential growth of students' enrollment rates. Although the enrollment rate for higher education shows more positive trends, higher education institutions still struggle to increase their enrollment rates (Purnastuti \& Izzaty, 2016). The total enrollment rate for higher education in Indonesia revolves around 8.04 million, which represents half of the United States, which has approximately 16.6 million enrollment rates for higher education in 2018. Geographical and social disparities which hinders access towards higher education in Indonesia. This is driven mainly by social inequality that mostly caused by the excessive financial burden on the household of supporting children for higher education (OECD/Asian Development Bank, 2015). The cost of higher education in Indonesia has also experienced massive growth over the past decade. The Indonesian government has increased the overall budget for education from IDR 1 trillion in 2009 to 1.89 trillion in 2014. However, the share spent on higher education institutions has decreased from $50.48 \%$ in 2013 to $48.97 \%$ in 2014 (OECD/Asian Development Bank, 2015).

The lack of government expenditure on the education sector has contributed to the expansion of low quality higher education that has sprung to absorb the demand for education that has not been fully met by the government. Indonesia's higher education institutions faced a significant challenge not only to improve their accessibility but to improve their overall quality. The Indonesian government aimed to develop a 'world-class' education system by 2025 (Roser, 2018). Based on the data that has been shown, the road to achieving an equal outcome of education might need a longer period of time since the cost of higher education has significantly increased, combined with the relatively lower government expenditure on higher education. Although there has been some increase in government spending on education, the overall expenditure is still comparatively low in comparison with Indonesia's regional peers.

The government has undergone several initiatives to increase accessibility, equity, and affordability towards higher education. Initiatives such as providing scholarships and other support structures have been implemented. However, such initiatives have not been very significant as scholarship offerings are relatively small in their financial support and do not fully benefit the most impoverished household (Purnastuti \& Izzaty, 2016). Seeing that the government spending is still comparatively low to other Indonesia's regional peer, it is unsurprising that several government initiatives to increase accessibility, equity, and affordability in attaining higher education has not been very successful in catering all groups of society. Higher education institutions in Indonesia is centrally governed under the Directorate General of Higher Education, and the Ministry of Religious Affairs for the Islamic higher education institutions. Seeing the size of Indonesia, added with numerous higher education institutions, it is very challenging for governments to efficiently higher education system in Indonesia. Indonesian governments are facing an insurmountable challenge in providing access to higher education, such as higher population, social and economic disparity, geographic disparity, and limited capacity and equity of education service. The number of public 
higher education institutions in Indonesia is substantially low compared to that of private institutions, leading to significant privatization and an increase in tuition costs.

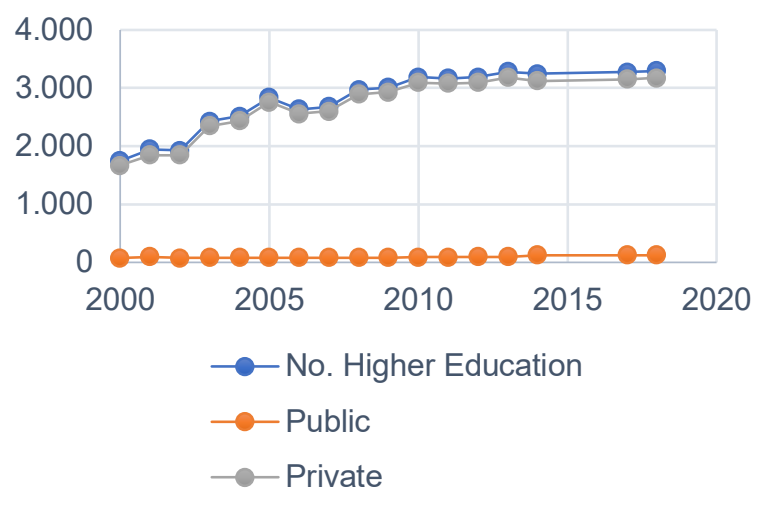

Figure 1.Higher education development in Indonesia from 2000-2018. (Adopted from the Ministry of Research, Technology and Higher Education Statistical Yearbook: 2000 - 2018)

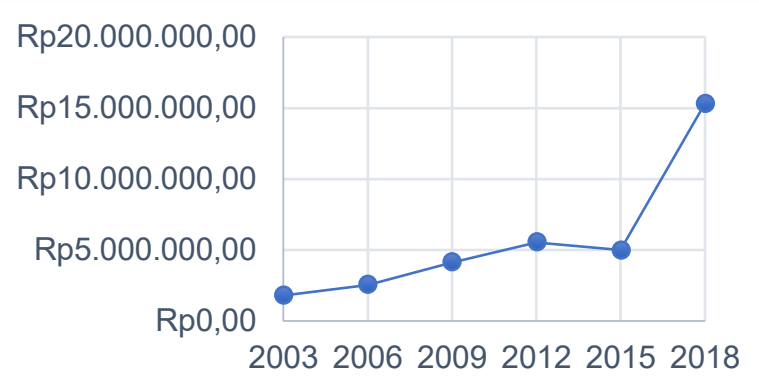

Figure 2.Higher Education Tuition in Indonesia, 2003-2018.(Adopted from the Indonesian Bureau of Statistics, Statistics of Education 2003 - 2018)

As shown in Figure 1 and Figure 2, Indonesia lacks the number of public institutions. This significantly increased the barriers to entry for those public institutions as the number of enrollment for such institutions kept on growing while the availability of seats in such institutions is severely limited. Students are left with a minimal option on which university they want to enroll since they are left with a variety of private institutions, which has a significantly higher cost compared to the public institutions. The data shows that the number of public institutions in Indonesia is remarkably low, standing at 122 public institutions compared to 3,171 private higher education spread across Indonesia. It indicates that there are too many private institutions in Indonesia. These institutions are often associated with a relatively low level of efficiency due to the small number of students they have (Purnastuti \& Izzaty, 2016). Seeing this trend of the massive increase in private education, it is not a new phenomenon to see a sharp rise in the cost of higher education tuition. This is shown in Figure 3, which highlighted a sharp increase in the cost of higher education from 2015 through 2018.

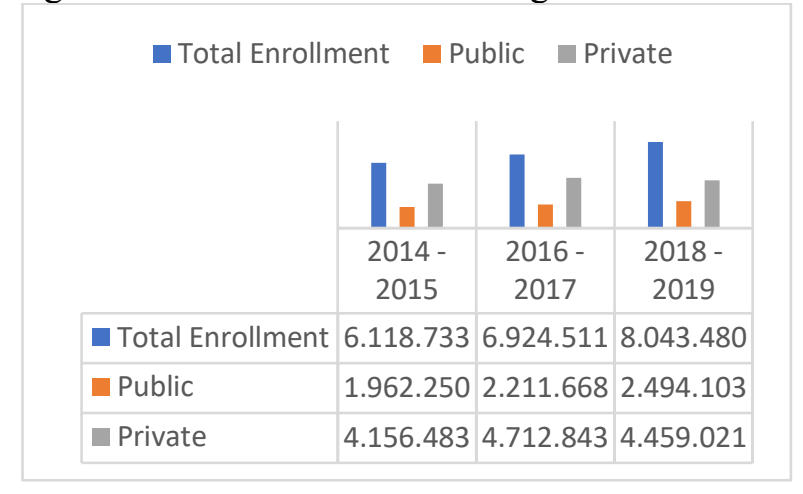

Figure 3.Higher Education Enrollment in Indonesia, 2014-2015, 2016-2017, 2018-2019. (Adopted from the Ministry of Research, Technology and Higher Education Statistical Yearbook: 2014 - 2018

The overall enrollment for higher education in Indonesia shows a steady increase. The number of students enrolled in public institutions is showing steady growth over the past few years compared to the slowly decreasing number of enrollments for private institutions. As such, with a severely limited number of public higher education in Indonesia, it is prevalent to see a very tight competition for students among public institutions. The number of students enrolled in public institutions increased from 1.9 million in $2014-2015$ to 2.4 million in 2018-2019. With a minimal amount of public institutions spread across Indonesia, students compete for a minimal seat with a slim chance of getting accepted in those institutions. This makes higher education a rather fierce and gruesome competition for students rather than providing equal opportunity. Public institutions are faced with a growing number of students from across Indonesia with very few seats, making them more exclusive compared to the other.

\section{Higher Education Overview in the United States}

The cost of higher education in the United States has been skyrocketing over the past decade. This has been one of the concerns echoed among student groups, especially those coming from a disadvantaged background, given the possibility that they may not be able to afford the overall cost 
of attaining higher education. Such a notion brings dilemmas both towards students and academic administrators. Persistently increasing the value of attaining higher education might be detrimental for students as students are blocked in such a "paywall," in which most students are forced to opt for taking student loans to finance their education. Such a strategy might be detrimental since this debt could be carried further down as they work, curbing their financial stability in the long run, which exacerbates social and economic inequalities. On the other hand, administrators at academic institutions are also facing such a dilemma. If they retain universities from increasing their tuition, wages of faculty members would remain constant and could fall below the earnings of people from other occupations. Hence, universities will struggle to retain the existing faculty members and attract new members (Ehrenberg, 2020).

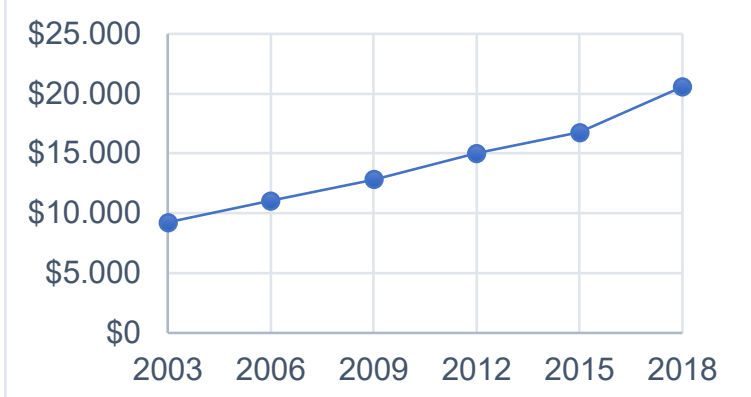

Figure 4.U.S Higher Education Average Tuition Fees in 2003 through 2018 (in U.S Dollars). (Adopted from the U.S Department of Education, National Center for Education Statistics 2003 through 2018)

Based on data showed in Figure 4, it shows the trends of college pricing from 2003 through 2018. The data shows that over the past fifteen years, the cost of higher education has doubled, which further strengthens the argument that college affordability has become a crisis in the United States as higher education tuitions keep growing. This pared-back the ability for students to obtain higher education degrees, especially those coming from a disadvantaged background. The National Center for Education Statistics (NCES) also noted that the United States is experiencing a decrease in higher education enrollment in 2010 through 2018. This contributed a large proportion of American students to opt for student loan debt service to assist in fiancé their higher education, making the level of indebtedness among U.S students substantially high. The increase in student loans has been the source of concern among academics and policymakers, highlighting the negative outlook of student loan debt towards economic outcomes in the long run (Ferretti, Jones, \& Mcintosh, 2015).

It is not a new phenomenon that such a notion sparked several discussions on whether higher education is a worthy investment. The return of value differs substantially across different fields of education. Top students are opted to attain a more selective institution with a more demanding and financially rewarding field of study. Hence, competition for students is often revolved around these fields of studies and institutions (Webber, 2014). Student enrollment decreased by $8 \%$ from 18.1 million to 16.6 million, and the projected student enrollment rate shows that by 2029 , the total enrollment rate for an undergraduate degree is expected to be 17.0 million students (Hussar, et al., 2020). This shows that participation in higher education, which reflected by enrollment rates are decreasing or relatively stagnant in the US.

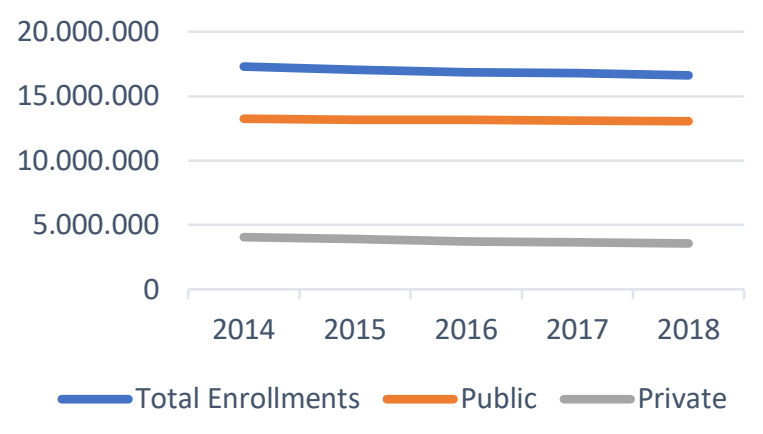

Figure 5.Total undergraduate fall enrollment in higher education institutions. (Adopted from the U.S Department of Education, National Center for Education Statistics 2014 through 2018)

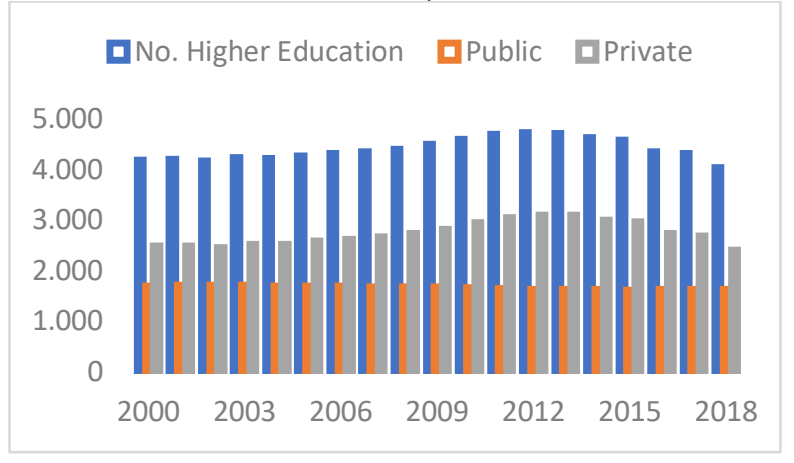

Figure 6.The Number of Higher Education in the U.S, 2000-2018. (Adopted from the U.S Department of Education, National Center for Education Statistics 2000 through 2018) 
As shown in Figure 5, the number of enrollment towards private institutions in the United States has decreased since 2015. In Figure 6, data shows that the development of private higher education has been declining in the United States from 2000 to 2018. These figures show that the trend for higher education institutions and enrollment in the United States is slowly and steadily decreasing, and this trend is projected to fall even further due to the emergence of COVID-19 that has taken a massive hit on higher education institutions. These conditions are challenging, seeing that much work needs to be done to make higher education more accessible, catering to a broader audience.

\section{COVID-19 and its Disrupting Effect on Higher Education in Indonesia and the United States}

The pandemic has hugely disrupted higher education. The enrolment rate for higher education is expected to fall due to COVID-19, and the future for higher education institutions are becoming even more uncertain since there are insufficient data to predict when the crisis will eventually subside. In addition, some students in the United States are expressing concern about whether paying full tuition for online distance learning is even worth the cost.

A recent survey conducted by the American Council on Education indicated as much as $86 \%$ of college presidents are putting fall or summer enrollment numbers at the top of their most pressing issues. This is followed by $64 \%$ that selected long term financial viability for higher education institutions (Turk, Soler, \& Vigil, 2020). Tuition and fees contributed to approximately $26 \%$ of revenues for four-year public institutions and 35\% for four-year private nonprofit institutions. The emergence of COVID-19 provides even more uncertainty for student enrollment, especially during fall. Only $25 \%$ of students agreed that they feel prepared for a remote freshman year of college compared to the $54 \%$ who are still hoping for an inperson first year (Kim, Khrisnan, Law, \& Rounsaville, 2020).

Indonesian higher education institutions are also experiencing similar problems due to the outbreak of COVID-19. Several private institutions are reportedly experiencing a decrease in student enrollment (Projo, 2020). In addition, the Indonesian government has decided that campuses should remain close for the fall. Hence, the teaching and learning method will most likely take place online until the end of the year 2020. There have been several arguments among certain groups, discussing the possibility of bankruptcy that might occur across higher education institutions. The falling of enrollment rates has slashed higher education's revenue. Most higher education institutions have incurred the cost that they should be spending for the upcoming semester. Figure 4 shows the national average for the trends in higher education enrolment rates in Indonesia. The data shows that the enrolment rate for private higher education institutions is fluctuating and seeing a decrease in 2018 (see Figure 5). Hence, it is very probable to see such a decline happening in 2020, seeing the current pandemic caused by COVID-19. Private higher education has the highest probability of shutting down as they are prone to have fewer students compared to the public. As of 2017, the total enrolment rates for private higher education in Indonesia reaches 550,359. In that same year, there are a total of 3,154 private higher education institutions in Indonesia. Dividing the number of student enrolments in 2017 by the total number of private higher education institutions in Indonesia, it is estimated that the enrolment rate for each private higher education institution lies around 175 students in 2017. These institutions are the ones who are at a higher risk of failing since they have a relatively lower income rate due to the lower student enrolment, specifically during COVID-19.

Furthermore, this pandemic has added challenges towards higher education institutions, seeing consumer spending has been massively curbed. A survey conducted by McKinsey \& Company (2020), shows that most Americans and Indonesians believe that it will take more than six months for the economy to recover fully. Such statements are reflected in Figure 8, where $52 \%$ of Indonesians and $49 \%$ of Americans are still unsure regarding economic recovery post-COVID-19. Seeing the uncertainty of consumers in Indonesia and the United States, consumption pattern might shift during the crisis and has the probability to stick in the long run. Lockdowns and other restriction measures have been detrimental to the economy, which the World Bank, in their latest report, concluded that the global economy would undergo contraction by $5.2 \%$ in 2020 (World Bank Group, 2020). The COVID-19 outbreak is unique to some extent since it triggers the higher possibility of a global recession that is caused solely by a pandemic. The economic downturn in 2020 will likely be the deepest one in an advanced economy, giving a 
profound impact on consumer patterns that may stick in the long run.

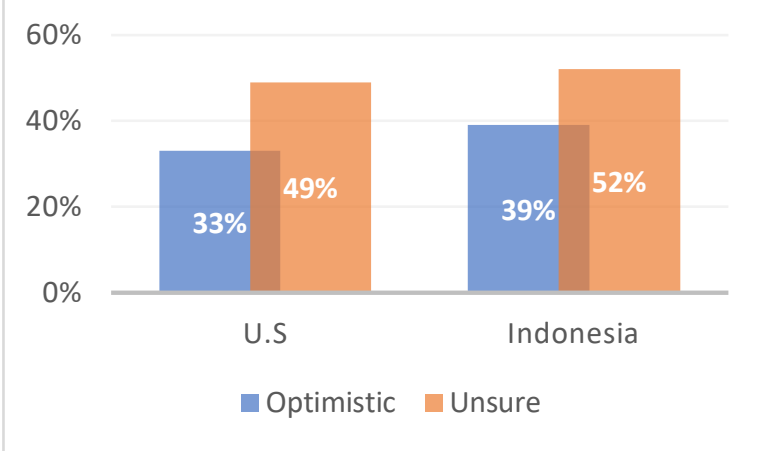

\section{Figure 7.Confidence in own Country's Economic Recovery After COVID-19, May 2020. (Adopted from McKinsey \& Company, U.S and Indonesia Consumer Sentiment During the Coronavirus Crisis 2020.)}

As seen in Figure 8, both Indonesia and the United States share a similar percentage of consumer perception during COVID-19. Consumers are paying more attention to the value they spent, which might alter consumption in the long run as they perceive it will take a significant amount of time for the economy to rebound back to its previous state. Hence, consumers are exercising more caution toward the money they spent. Seeing the nature of consumers during the outbreak of COVID-19, it is unsurprising that higher education might need to shift its method of learning and adjust how they should charge their students to cater to a broader audience, particularly during a crisis. The opportunity to develop an open online education during this pandemic is substantially high, seeing that most societies are shifting towards online services due to the current situation, which forces them to stay indoors. The nature of online education itself has been promising due to its affordability compared to the regular in-person classroom. Higher education institutions face inevitability in experiencing disruption due to the emergence of COVID-19. There is a growing probability that campuses will remain close for a certain period. Hence, this calls for an immediate digital transformation within the higher education institutions to build mature digital learning ecosystems to cater to the needs of its students during the crisis (DeVaney, Shimshon, Rascoff, \& Maggioncalda, 2020). Universities can employ various methods and strategies for disseminating their subjects or materials. Lectures that require less personalization or human interaction could be recorded, provided with multi-media presentations where students can participate in such subjects at their own pace. Such a method could be commoditized at a much lower cost, which can cater to a broader audience (Govindarajan \& Srivastava, 2020). In order to achieve those, higher education institutions need to commit more of its resources for teaching based research to focus on viable and effective methods that should be employed for online distance learning.

There has been a growing number of discussions surrounding the transformative potential of technology in education or EdTech. EdTech is defined as the combination of information, communication, and technology (ICT) in the education sphere. Such a combination holds a considerable advantage in the education sector. In the case of Indonesia, the growth of EdTech has shown some promising trends since the newly appointed Minister of Education expressed a strong interest in utilizing technology for learning. The growth of EdTech has mainly driven by the private sector compared to the public sector. The COVID19 crisis has forced the education sector to leverage the use of EdTech in their learning and teaching method, which is expected to have a profound impact in the long run. Programs and policies to promote the use of EdTech are imperative and crucial to the expansion of access to quality of education. In the United States, a platform such as Coursera, Udacity, edX has partnered with top universities to deliver some of their content online with an added subscription to receive a certificate.

Indonesian EdTech is growing at a relatively fast pace, catching up with the global frontiers over the past six years. However, such growth also comes with a certain bottleneck where most of Indonesia's EdTech companies are facing challenges of low profitability due to the lack of funding. This is partly due to the general perception of EdTech as a low-yielding enterprise compared to the other, more promising technology startups (World Bank, 2020). EdTech investors are facing major hurdles in conducting investment. This has mostly occurred, seeing that most EdTech consumers have a relatively low willingness to pay. This is prevalent from the perspective of parents, which generally do not tend to see the value of paying additional education services, especially if these services are conducted online. Most teachers, learning facilitators in Indonesia also have a relatively low level of digital literacy, which makes digitizing education even more challenging. Aside from that, Indonesia also has a relatively low-level digital infrastructure to support a fully online learning education. This infrastructure inequality is 
prevalent primarily off the island of Java, which hampers EdTech penetration and dissemination across all provinces (World Bank, 2020).

The challenges of utilizing EdTech in Indonesia are also prevalent in the United States. Even though the percentage of faculty members who have experienced teaching online courses continues to grow, currently, only $46 \%$ of United States college faculty members have taught an online course. There has been a relatively lower number of faculty members in the United States that have experienced teaching hybrid classes or combining in-person interaction and online elements. The same problem persists in the United States, where only $32 \%$ of faculty members expressed positive attitudes towards online education compared to $36 \%$ who completely disagree. Faculty members tend to have a relatively negative perception towards online courses' capability to achieve the same quality of outcomes as face-to-face interaction (Jaschik \& Lederman, 2019). For students, affordability ranks the most significant determinant for online college students, followed by the reputation of the school of program. As much as $36 \%$ of college students choose the least expensive program during their selection process, making price the prime determinant in making decisions. However, $64 \%$ of students are willing to spend more depending on the school or program reputation $(39 \%)$ and whether the program is paralleled with their needs $(25 \%)$ (Magda, Capranos, \& Aslanian, 2020). Students are putting their focus on the value of education. These values differ, ranging from three factors: cost, reputation, courses. The three factors contributed as a determinant for student's decision making as students want to maximize the value they received by attaining online education.

Outlining the separate challenges faced by both Indonesia and the United States, it is projected that the rate of disruption between both countries will differ. The emergence of EdTech has been prevalent in both Indonesia and the United States. In Indonesia, EdTech startup companies and initiatives are relatively new to implement. Hence, it is unsurprising to see a relatively low societal awareness of such a method. Combined with the relatively low digital literacy among teachers and unequal distribution of digital infrastructure, particularly off the island of Java, Indonesia could see a long way in fully harnessing EdTech. Digital infrastructure is one of the focal points that need to be addressed. The uncertainty of this crisis should provide a catalyst for the Indonesian government and education institutions to build a more robust digital infrastructure. This is imperative for public higher education institutions.

Indonesia severely lacks in public institutions with only 122 public higher education, making competition to enter public higher education insurmountably challenging. The critical difference in Indonesian higher education institutions compared to the United States is the rate of enrollment that is still increasing. Even though the total number of enrollment is still half of the United States, Indonesia still shows a promising future for higher education participation due to its steadily increasing number. While in the United States, the cost of attaining higher education is the prime determinant for students. With the crisis of COVID-19 severely downcutting consumer sentiment to an all-new low, higher education institutions in the United States need to rethink on how they could charge their students. The initiatives on higher education institutions in Indonesia heavily lies on the government since such institutions are centrally governed under the Minister of Education and Culture and the Minister for Religious Affairs for Islamic institutions. Hence, in this case, most of the initiatives lie on the government's capability to construct a robust digital infrastructure, bolstering technological literacy by providing training for teachers or lecturers. The development of technology is imperative for higher education. Moving from the traditional in-person interaction to more online and open education is needed, particularly during the crisis of COVID-19, which caused most campuses and classes to shift online.

EdTech in higher education is supposed to make disseminating knowledge much more effective, efficient, and able to reach larger audiences. Thus, harnessing such tools in higher education should make higher education more accessible. Looking at the current challenges that persist in higher education institutions and the growing development of technology for education, this pandemic should provide an even greater opportunity for open education to expand. Adaptation for technology that has occurred during this pandemic is irreversible, even though the adjustment has been challenging for many higher education institutions in Indonesia. It is unsurprising to see that blended learning will potentially become the 'new normal' for education, notably higher education institutions in Indonesia. While in the United States, the price has been the most significant factor in determining access to 
higher education. Higher education institutions have become more expensive in the United States, and the price trends are projected to increase even further. However, enrollment rates have shown a slow decline over the past few years, and it is expected to fall even further due to COVID-19. It is unsurprising that people tend to be more cautious and maximizing the value of what they spent, particularly during crises. Thus, it is unsurprising that some students and their parents are reluctant to pay the full price of their tuition costs during the pandemic. The pandemic will possess a higher probability of shrinking the number of private higher education in the United States since student enrollment continually declines. The relatively low consumer sentiment in the United States has prompted a large portion of the society to remain vigilant towards the money they spent. This shift in consumer patterns will have the probability to change the nature of how higher education institutions will price their students.

With the campuses and universities closed during the course of the pandemic, it is prevalent to see such behavior in students when determining whether or not they will enroll in higher education. Hence, higher education institutions need to adjust the way they priced their students, making it more affordable. Seeing most campuses shut down their in-person classes to curb the spread of COVID-19, higher education needs to rethink their pricing strategy in the short and long term. Consumers are becoming more conservative, particularly during times of crisis. Hence, it is imperative for higher education to rethink their strategy on how they should price their students. In addition, higher education institutions need to expand their capacity by diversifying their online classes to cater to a broader audience. This should expand accessibility towards higher education, making it easier for students to receive a quality education. The trajectory of disruption towards higher education institutions in the United States will most probably be left to the universities as a driving factor to enhance innovation compared to Indonesia whom mostly relies on the government as the driving factor for revamping higher education. It is expected that the 'new normal' for higher education institutions in Indonesia and the United States will mostly shift towards hybrid learning, and this will have a higher potential to stick in the long run.

\section{CONCLUSION}

Discussions surrounding the problems found in higher education institutions are profound across scholars over the past decades. This paper applied comparative analysis to provide a contextual overview of the ecosystem of higher education in Indonesia and the United States and how the pandemic will create a different trajectory of disruption in higher education between two countries. The persistent increase in the cost of attaining higher education has been concerning, particularly for those coming from a disadvantaged background. Higher education institutions in Indonesia still struggles to increase its participation rate. The United States also faced similar existing problems in its higher education institutions. The rising cost of higher education has concerned students, as most of them are opted to use student loan debt services to finance their education. The overall number of enrolment rates for higher education is slowly declining in the United States. This is followed by the number of private universities which are declining over the past few years.

The crisis of COVID-19 has hugely struck higher education institutions since campuses are forced to close during the pandemic. Indonesia is struggling to use EdTech in higher education effectively. The lack of digital infrastructure, followed by the lower rate of digital literacy among teachers, has prompted insurmountable challenges faced by Indonesia's higher education institutions during the pandemic. Moreover, there has been a collective number of students and parents expressing their concern on whether paying the full price of tuition worth the value they received. Such behavior is prevalent, seeing that most higher education institutions are imposing online distance learning. Higher education is expected to experience an imminent disruption due to COVID19.

However, the trajectory of the disruption between the two countries will differ, seeing the different landscape faced by each country. In Indonesia, the government plays a vital role in fostering innovation. This will mostly differ in the United States, seeing that the current enrolment rate for attaining higher education is slowly declining and is projected to decline even further due to the pandemic. Higher education in the United States needs to disrupt the way they priced their students and making access to higher education more affordable. It is foreseen that higher education will 
alter their learning and teaching methods in the long term since most higher education institutions are opted to use online distance learning during the pandemic. The effective utilization of EdTech in higher education institutions is determined by the maturity of infrastructure and institutions to synergize on building an efficient ecosystem for higher education. The pandemic has shown the need for systemic institutional changes to further develop higher education institutions to cater to the need for a more diverse audience.

\section{REFERENCES}

Christensen, C. M., \& Eyring, H. J. (2011). The Innovative University: Changing the DNA of Higher Education from the Inside Out. San Francisco: Jossey-Bass.

DeVaney, J., Shimshon, G., Rascoff, M., \& Maggioncalda, J. (2020, May 05). Higher Ed Needs a Long-Term Plan for Virtual Learning. Harvard Business Review, pp. 2-5.

Dickler, J. (2020, May 6). Demand for refunds intensifies among college students. Retrieved June 30, 2020, from CNBC: https://www.cnbc.com/2020/05/06/demandfor-refunds-intensifies-among-collegestudents.html

Ehrenberg, R. G. (2020). The economics of tuition and fees in American higher education. Retrieved June 26, 2020, from https://doi.org/10.1016/B978-0-12-8153918.00025-2

Ferretti, F., Jones, S., \& Mcintosh, B. (2015). Economic growth and the harmful effects of student loan debt on biomedical research. Economic Modelling, 49, 308-313.

Govindarajan, V., \& Srivastava, A. (2020, March 31). What the Shift to Virtual Learning Could Mean for the Future of Higher Ed. Harvard Business Review.

Haryanto, J. O. (2020, June 16). Bangkrutnya Universitas. Bisnis Indonesia, pp. 1-20.

Hussar, B., Zhang, J., Hein, S., Wang, K., Roberts, A., Cui, J., . . . Dilig, R. (2020). The Condition of Education 2020 (NCES 2020-144).
Washington, DC: U.S. Department of Education.

Jaschik, S., \& Lederman, D. (2019). The 2019 Inside Higher Ed Survey of Faculty Attitudes on Technology. Washington DC: Inside Higher Ed and Gallup.

Kim, H., Khrisnan, C., Law, J., \& Rounsaville, T. (2020). COVID-19 and U.S. higher education enrollment: Preparing leaders for all. New Jersey: McKinsey \& Company.

Magda, A. J., Capranos, D., \& Aslanian, C. B. (2020). Online College Students 2020: Comprehensive Data on Demands and Preferences. Louisville, KY: Wiley Education Services.

OECD/Asian Development Bank. (2015). Education in Indonesia: Rising to the Challenge. Paris: OECD Publishing.

Projo, W. A. (2020, April 17). Wabah Corona, Penerimaan Mahasiswa Baru di Sejumlah Kampus Swasta Menurun. Retrieved June 30, 2020, from Kompas.com: https://www.kompas.com/edu/read/2020/04/17/ 070000171/wabah-corona-penerimaanmahasiswa-baru-di-sejumlah-kampus-swastamenurun

Purnastuti, L., \& Izzaty, R. E. (2016). Access and Equity in Higher Education in Indonesia: A Review from the Periphery. In M. Shah, A. Bennet, \& E. Southgate (Eds.), Widening Higher Education Participation: A Global Perspective (pp. 119134). Waltham, MA: Elsevier.

Roser, A. (2018, February 21). Beyond Access: Making Indonesia's Education System Work. Retrieved July 9, 2020, from Lowy Institute: https://www.lowyinstitute.org/publications/bey ond-access-making-indonesia-s-educationsystem-work\#sec34421

Turk, J. M., Soler, M. C., \& Vigil, D. (2020). College and University Presidents Respond to COVID-19: April 2020 Survey. Washington DC: American Council on Education.

Webber, D. (2014). Is the return to education the same for everybody? IZA World of Labor (92), 1-10.

World Bank. (2020). EdTech In Indonesia - Ready for Take-off? Washington DC: The World Bank.

World Bank Group. (2020). Global Economic Prospects: June 2020. Washington, DC: The World Bank. 